\title{
CATION ACCUMULATION BY MUSCLE TISSUE: THE DISPLACE- MENT OF POTASSIUM BY RUBIDIUM AND CESIUM IN THE LIVING ANIMAL 1,2
}

\author{
By ARNOLD S. RELMAN, ANNE T. LAMBIE, BELTON A. BURROWS, AND \\ ARLENE M. ROY WITH THE TECH NICAL ASSISTANCE OF JACQUELYN M. ALLEN, \\ HELEN P. CONNORS, AND ELISABETH S. DELL \\ (From the Evans Memorial Department of Clinical Research and Preventive Medicine, Mas- \\ sachusetts Memorial Hospitals, The Radioisotope Service, Boston Veterans Ad- \\ ministration Hospital, and the Department of Medicine, Boston Uni- \\ versity School of Medicine, Boston, Mass.)
}

(Submitted for publication March 4, 1957 ; accepted April 11, 1957)

The mechanism responsible for the selective accumulation of potassium by muscle cells is not known. A theory which has gained wide acceptance in recent years is that potassium passively diffuses into muscle cells along an electrical gradient maintained by the active extrusion of sodium (1-4). According to this view, the negative potential normally found inside the muscle cell is produced by this "sodium pump," and in turn causes the accumulation of potassium against a concentration gradient.

If sodium were the only cation transported actively by the muscle cell, and if the accumulation of potassium were entirely a matter of passive diffusion down an electrical gradient, then one would expect other univalent cations capable of penetrating cells to distribute themselves at equilibrium across the muscle cell membrane in the same concentration ratio as potassium. Rubidium and cesium, univalent alkali metals with physicochemical characteristics closely resembling those of potassium, would appear to be ideally suited for testing this hypothesis. These cations penetrate cells readily and can substitute for potassium in many biological processes (5).

In the experiments reported here an attempt was made to test the theory of passive uptake of potassium by comparing the equilibrium distribution of potassium with that of rubidium or cesium in the muscle tissue of growing rats fed equivalent, large quantities of these elements. Previous

1 This study was supported in part by grants from the Greater Boston Chapter of the Massachusetts Heart Association, and from the Atomic Energy Commission (Contract AT 30-10-919, with the Massachusetts Memmorial Hospitals).

2 Presented in part at the Annual Meeting of the American Federation for Clinical Research, May, 1956. studies (6-9) have already established in a general way that animal tissues are capable of accumulating significant quantities of rubidium or cesium, but there have been no determinations of the tissue-plasma concentration gradients when organisms are fed non-tracer amounts of these substances and no quantitative measurements of the extent to which these ions are taken up by tissues relative to potassium. The results of the present work indicate a distinctly greater affinity of rat muscle tissue for rubidium and cesium than for potassium, and the data therefore suggest that processes more complex than simple diffusion are involved in the normal accumulation of potassium.

\section{METHODS}

Young male rats of the Sprague-Dawley strain weighing 100 to 150 grams were depleted of potassium and made alkalotic by the feeding of a potassium-free alkalineash diet (10) for a period of two weeks. At the end of this time the animals were divided into five groups. Group I, the potassium-deficient controls (12 animals), was sacrificed at the end of the two-week period of potassium-depletion. Group II, the potassium-added controls (11 animals), was maintained for two more weeks on the same diet but $20 \mathrm{mEq}$. per $\mathrm{L}$. of $\mathrm{KCl}$ was added to the drinking water. Group III, the two week rubidium group ( 30 animals), was given $20 \mathrm{mEq}$. per L. of $\mathrm{KCl}$ plus $20 \mathrm{mEq}$. per $\mathrm{L}$. of $\mathrm{RbCl}$ in the drinking water for a period of two weeks. Group IV, the three-week rubidium group (17 animals), was treated in the same way as Group III, but it was allowed to drink the $\mathrm{KCl}$ and $\mathrm{RbCl}$ mixture for three weeks. Group $\mathrm{V}$, the two-week cesium group ( 17 animals), was given a mixture of 20 $\mathrm{mEq}$. per $\mathrm{L}$. of $\mathrm{KCl}$ and $20 \mathrm{mEq}$. per $\mathrm{L}$. of $\mathrm{CsCl}$ in the drinking water for two weeks following the period of potassium depletion. In addition, there was a separate group of animals, Group VI, the normal controls (12 animals). These animals were not initially depleted of potassium, but were maintained for three weeks on the experimental diet, plus $20 \mathrm{mEq}$. per $\mathrm{L} . \mathrm{KCl}$ in their 
TABLE I

Plasma concentration

\begin{tabular}{|c|c|c|c|c|c|c|c|}
\hline Group & No. & $\mathrm{Na}$ & $\mathbf{K}$ & $\mathbf{R} \mathbf{b}$ & $\mathrm{C}_{8}$ & $\mathrm{CO}_{2}$ & $\mathbf{C l}$ \\
\hline I. K-deficient controls & 12 & $\begin{array}{c}m E q . / L . \\
139.0 \\
\pm 1.9\end{array}$ & $\begin{array}{r}m E q . / L \\
1.6 \\
\pm 0.2\end{array}$ & $m E q . / L$ & $m E q . / L$ & $\begin{array}{c}m E q . / L \\
31.7 \\
\pm 2.9\end{array}$ & $\begin{array}{r}m E q . / L . \\
90.6 \\
\pm 2.7\end{array}$ \\
\hline II. K-added controls & 11 & $\begin{array}{l}146.1 \\
\pm 2.0\end{array}$ & $\begin{array}{r}3.7 \\
\pm 0.6\end{array}$ & & & $\begin{array}{r}29.4 \\
\pm 2.9\end{array}$ & $\begin{array}{r}99.4 \\
\pm 2.7\end{array}$ \\
\hline III. Two-week Rb & 30 & $\begin{array}{l}141.4 \\
\pm 5.2\end{array}$ & $\begin{aligned} & 1.9^{*} \\
\pm & 0.4\end{aligned}$ & $\begin{array}{r}0.86 \\
\pm 0.47\end{array}$ & & $\begin{array}{r}20.3 \\
\pm 2.5\end{array}$ & $\begin{array}{l}106.6 \\
\pm 2.5\end{array}$ \\
\hline IV. Three-week Rb & 17 & $\begin{array}{l}140.4 \\
\pm 3.5\end{array}$ & $\begin{aligned} & 1.2 \dagger \\
\pm & 0.4\end{aligned}$ & $\begin{array}{r}0.83 \\
\pm 0.20\end{array}$ & & $\begin{array}{r}18.4 \\
\pm 3.2\end{array}$ & $\begin{array}{l}108.5 \\
\pm 3.8\end{array}$ \\
\hline V. Two-week Cs & 17 & $\begin{array}{l}144.9 \\
\pm 4.8\end{array}$ & $\begin{array}{r}2.0 \\
\pm 0.7\end{array}$ & & $\begin{array}{r}0.55 \\
\pm 0.11\end{array}$ & $\begin{array}{l}24.1 \ddagger \\
\pm 3.5\end{array}$ & $\begin{array}{l}101.4 \\
\pm 4.3\end{array}$ \\
\hline VI. Normal controls & 12 & $\begin{array}{l}142.1 \\
\pm 3.5\end{array}$ & $\begin{array}{r}3.9 \\
+0.3\end{array}$ & & & $\begin{array}{r}27.2 \\
\pm 1.5\end{array}$ & $\begin{array}{r}100.6 \\
\pm 1.8\end{array}$ \\
\hline
\end{tabular}

* Sixteen analyses.

$\dagger$ Four analyses.

‡ Seven analyses.

drinking water. The animals were allowed access to drinking water ad libitum, so that the exact intake of each of the added cations was not measured, but in every animal given rubidium or cesium plus potassium the intake of each of the two cations was always equal. The purity of all the rubidium and cesium salts used was always checked either by differential precipitation and weighing as the sulfate salt or by paper chromatography (11).

At the end of each experiment the animals were exsanguinated through the abdominal aorta, under light amytal anesthesia. The blood was immediately heparinized and the plasma separated by centrifugation under oil. Samples of skeletal muscle were dissected free of all obvious fat and connective tissue, minced, and then extracted in hot water. The completeness of extraction of all the muscle cations measured was verified by a comparison of this method with a dry-ashing technique. Plasma analyses for sodium, chloride and $\mathrm{CO}_{2}$ content were carried out by flame photometry, modified Volhard titration, and standard manometric technique, respectively. Similar methods were applied to the determination of sodium and chloride in the aqueous extracts of muscle. In the control animals not given rubidium or cesium, determinations of potassium in the plasma and muscle extracts were carried out by flame photometry. In all other experiments in which plasma and muscle extracts contained mixtures of potassium and rubidium, or potassium and cesium, special techniques had to be used for the simultaneous analysis of these elements.

The procedure devised was a combination of chemical analysis and radioisotope-tracer technique. All rubidium or cesium used in any one experiment was labeled at the beginning of the experiment by the addition of radioactive rubidium $86^{3}$ or cesium $134^{3}$ to the drinking water.

8 Obtained from Abbott Laboratories.
The purity of the radioactive tracers was checked in every instance by plotting decay curves. Since all cesium or rubidium had been added to the diet at a known and constant specific activity, it was possible to determine the concentration of rubidium or cesium in any sample simply by measurement of its radioactivity. The total content of potassium plus rubidium, or potassium plus cesium in the sample, was then determined by the method of chloroplatinate titration (12). This latter technique was found to give essentially complete recoveries of standard mixtures of potassium, rubidium and cesium in serum and in muscle extracts. Knowing the sum of the alkali ions and the content of rubidium or cesium, it was then possible to calculate potassium as the difference between these two values.

All the data reported here were obtained by the "combined" method described above. Later on it was found possible to use flame photometry for the analysis of certain potassium and cesium mixtures, and in a number of experiments analyses were simultaneously carried out by both methods and found to give satisfactory agreement. In a few experiments, not reported here, mixtures of the alkali metals were separated by paper chromatography (11), and then each ion was eluted separately in water and determined by flame photometry. Comparison of this method with the "combined" radioactive-chloroplatinate technique used in the present study also gave a satisfactory correlation (13).

Intracellular concentration was expressed in terms of "intracellular water," which was taken as the difference between total water and "extracellular water." Total muscle water was determined by drying whole wet tissue to constant weight. "Extracellular water" was calculated from the chloride space on the assumption that chloride was exclusively extracellular in position. A constant correction for fat of 1 per cent of whole wet muscle weight was applied to each tissue specimen. 
RESULTS

Most of the animals appeared to tolerate the feeding of rubidium or cesium very well for the first two weeks. Having virtually stopped their normal growth during the two-week preliminary period of potassium deficiency, the rats began to gain weight and grow again at an almost normal rate during the initial period of feeding the rubidium-potassium and cesium-potassium mixtures. However, after about two weeks signs of toxicity began to appear, consisting chiefly of neuromuscular irritability and cessation of growth. Attempts to continue the feeding of rubidium beyond three weeks and the feeding of cesium beyond two weeks resulted in a progressively higher mortality, with the animals usually dying in convulsions.

The analytical data are summarized in Tables I and II. In these Tables the figures given are the group means, plus or minus the standard deviation of the observed values. In each instance the number of analyses is equal, or nearly equal, to the number of animals in the group. The few instances in which the number of analyses is significantly less than the number of animals are appropriately indicated. These discrepancies were the result of random technical difficulties caused by the small quantities of material available for analysis. In every case, however, all analyses actually carried out are included in the mean.
In the ensuing discussion whenever differences between means are called "significant," it is meant that the " $t$-test" gives values of "P" less than 0.01 . "Borderline significance" denotes "P" values greater than 0.01 but less than 0.05 .

\section{A. Plasma}

The results of the plasma values are summarized in Table I. The data demonstrate the following points :

1. Two weeks on the $\mathrm{K}$-deficient, alkaline-ash diet (Group I) resulted in the expected hypokalemic alkalosis with significant reductions in plasma concentration of potassium and chloride and a significant rise in plasma $\mathrm{CO}_{2}$ content compared to the normal controls (Group VI). The mean values were: potassium, $1.6 \mathrm{mEq}$. per L.; chloride, $90.6 \mathrm{mEq}$. per L.; and $\mathrm{CO}_{2}, 31.7 \mathrm{mEq}$. per L.

2. Addition of $20 \mathrm{mEq}$. per L. $\mathrm{KCl}$ to the drinking water for two weeks (Group II) resulted in virtual disappearance of these changes. Although the mean plasma values for potassium $(3.7 \mathrm{mEq}$. per L.), $\mathrm{CO}_{2}$ (29.4 mEq. per L.), and chloride ( $99.4 \mathrm{mEq}$. per L.) were not quite back to normal, the differences from normal were not significant.

3. When potassium-depletion was followed by the addition of a mixture of $\mathrm{KCl}(20 \mathrm{mEq}$. per L.) and $\mathrm{RbCl}(20 \mathrm{mEq}$. per L.) to the drinking water

TABLE II

Muscle composition per liter intracellular water

\begin{tabular}{|c|c|c|c|c|c|c|c|c|}
\hline Group & No. & $\mathbf{N a}$ & $\mathbf{K}$ & $\mathbf{R b}$ & Cs & $\boldsymbol{z}_{1} *$ & 2 zt & ICW \\
\hline I. K-deficient controls & 12 & $\begin{array}{r}m E q . / L \\
60.7 \\
\pm 11.6\end{array}$ & $\begin{array}{r}m E q . / L \\
107.1 \\
\pm 20.9\end{array}$ & $m E q . / L$ & $m E q . / L$ & $\begin{array}{c}m E q . / L \\
107.1 \\
\pm 20.9\end{array}$ & $\begin{array}{r}m E q . / L \\
167.8 \\
\pm 18.9\end{array}$ & $\begin{array}{c}\text { ml./Kg. tissue } \\
600.0 \\
\pm 14.3\end{array}$ \\
\hline II. K-added controls & 11 & $\begin{array}{r}10.0 \\
\pm 8.8\end{array}$ & $\begin{array}{r}168.8 \\
\pm 12.1\end{array}$ & & & $\begin{array}{r}168.8 \\
\pm 12.1\end{array}$ & $\begin{array}{l}178.4 \\
\pm 6.4\end{array}$ & $\begin{array}{r}598.8 \\
\pm 12.7\end{array}$ \\
\hline III. Two-week Rb & 30 & $\begin{array}{r}4.2 \\
\pm 2.6\end{array}$ & $\begin{array}{r}75.4 \\
\pm 11.7\end{array}$ & $\begin{array}{r}90.7 \\
\pm 11.8\end{array}$ & & $\begin{array}{l}166.1 \\
\pm 8.0\end{array}$ & $\begin{array}{l}170.2 \\
\pm 7.3\end{array}$ & $\begin{array}{r}609.3 \\
\pm 11.6\end{array}$ \\
\hline IV. Three-week Rb & 17 & $\begin{array}{r}3.4 \\
\pm 3.7\end{array}$ & $\begin{array}{r}64.2 \\
\pm 7.5\end{array}$ & $\begin{array}{l}100.5 \\
\pm 8.2\end{array}$ & & $\begin{array}{l}164.7 \\
\pm 9.8\end{array}$ & $\begin{array}{r}168.0 \\
\pm 11.0\end{array}$ & $\begin{array}{r}601.6 \\
\pm 17.4\end{array}$ \\
\hline V. Two-week Cs & 17 & $\begin{array}{l}9.88 \\
\pm 5.6\end{array}$ & $\begin{array}{r}75.1 \\
\pm 8.1\end{array}$ & & $\begin{array}{r}96.8 \\
\pm 9.7\end{array}$ & $\begin{array}{r}171.9 \\
\pm 12.2\end{array}$ & $\begin{array}{l}182.48 \\
\pm 14.8\end{array}$ & $\begin{array}{r}599.2 \\
\pm 15.7\end{array}$ \\
\hline VI. Normal controls & 12 & $\begin{array}{r}6.4 \\
\pm 3.9\end{array}$ & $\begin{array}{l}171.1 \\
\pm 8.2\end{array}$ & & & $\begin{array}{l}171.1 \\
\pm 8.2\end{array}$ & $\begin{array}{l}177.4 \\
\pm 5.1\end{array}$ & $\begin{array}{r}625.8 \\
\pm 22.8\end{array}$ \\
\hline
\end{tabular}

* $\Sigma_{1}=K+R b$ (or $\mathrm{Cs}$ ).

$+\Sigma_{2}=K+R b$ (or $\mathrm{Cs}$ ) $+\mathrm{Na}$.

$\ddagger \mathrm{ICW}=$ Intracellular water.

Eleven analyses only. 
for two weeks (Group III) the low plasma potassium remained essentially unchanged $(1.9 \mathrm{mEq}$. per L.), but there resulted a hyperchloremic acidosis, with a significant reduction in $\mathrm{CO}_{2}$ and a significant rise in chloride, compared to both the normals (Group VI) and the $\mathrm{K}$-added controls (Group II). The mean $\mathrm{CO}_{2}$ was $20.3 \mathrm{mEq}$. per $\mathrm{L}$., and the mean chloride $106.6 \mathrm{mEq}$. per $\mathrm{L}$. Plasma rubidium was very low $(0.86 \mathrm{mEq}$. per L.) - significantly lower than even the potassium concentration.

4. Continuation of the $\mathrm{RbCl}$ and $\mathrm{KCl}$ mixtures for a third week (Group IV) resulted in no definite further change in plasma composition, although there was a further reduction in $\mathrm{CO}_{2}$ of borderline significance. The apparent further reduction in plasma potassium to $1.2 \mathrm{mEq}$. per $\mathrm{L}$. may not be real since it was based on only four analyses.

5. Addition of a mixture of $\mathrm{KCl}(20 \mathrm{mEq}$. per L.) and $\mathrm{CsCl}(20 \mathrm{mEq}$. per L.) to the drinking water for two weeks following the initial period of potassium depletion (Group V) resulted in a reduction of $\mathrm{CO}_{2}$ content significantly less than that produced by the $\mathrm{KCl}$ and $\mathrm{RbCl}$ mixtures. The $\mathrm{CO}_{2}$ content $(24.1 \mathrm{mEq}$. per L.), although significantly lower than in the $\mathrm{K}$-deficient controls (Group I), was not significantly below the normal level (Group VI). Plasma potassium was low (2.0 mEq. per L.), and was not significantly different from the values in the rubidium groups (III and IV) or the K-deficient controls (Group I). Plasma cesium was only $0.55 \mathrm{mEq}$. per L., a value significantly lower than the simultaneous potassium concentration.

\section{B. Muscle}

Table II summarizes the results of the muscle analyses. The noteworthy findings were:

1. As expected intracellular potassium was low (107.1 mEq. per L.) and sodium high (60.7 mEq. per L.) in the K-deficient controls (Group I), as compared to the normal values in Group VI. There was a small but significant reduction in calculated intracellular water.

2. Addition of $20 \mathrm{mEq}$. per $\mathrm{L}$. $\mathrm{KCl}$ to the drinking water for two weeks (Group II) virtually restored muscle composition to normal, there being no significant differences in intracellular $\mathrm{Na}$ and $\mathrm{K}$ between Groups II and VI. Intracellular water remained the same as in the $\mathrm{K}$-deficient controls.

3. Addition of $20 \mathrm{mEq}$. per L. each of $\mathrm{RbCl}$ and $\mathrm{KCl}$ to the drinking water of the $\mathrm{K}$-deficient rats resulted, after two weeks, in striking changes in muscle composition (Group III). Potassium was significantly reduced still further to a concentration of $75.4 \mathrm{mEq}$. per L. (less than half of normal) and sodium was lowered to $4.2 \mathrm{mEq}$. per L. Intracellular rubidium was $90.7 \mathrm{mEq}$. per L. (significantly higher than potassium) and the total measured intracellular cation $\left(\Sigma_{2}\right)$ was normal. Intracellular water was essentially the same as in Groups I and II.

4. Continuation of the $\mathrm{RbCl}$ and $\mathrm{KCl}$ mixture for a third week (Group IV) resulted in a slight further drop in cellular potassium $(64.2 \mathrm{mEq}$. per L.) and sodium (3.4 mEq. per L.), as well as a further rise in cellular rubidium $(100.5 \mathrm{mEq}$. per L.). The difference in potassium content between the two- and three-week muscles was significant, but the difference in rubidium content was only of borderline significance.

5. Two weeks of treatment with a mixture of $\mathrm{CsCl}$ and $\mathrm{KCl}$ (Group V) lowered intracellular potassium to $75.1 \mathrm{mEq}$. per L. and sodium to 9.8 $\mathrm{mEq}$. per L. Intracellular cesium was $96.8 \mathrm{mEq}$. per L. (significantly higher than the simultaneous potassium levels), but total cation and intracellular water were essentially the same as in the $\mathrm{K}$-added and $\mathrm{K}$-deficient controls.

\section{Concentration ratios}

Table III summarizes the mean distribution ratios for potassium, rubidium and cesium. As shown in the third column, the normal ratio of intracellular to extracellular potassium was $44.2 \pm$ 4.1 (Group VI). Potassium deficiency caused a slight but significant elevation in this ratio to $67.7 \pm 16.2$. In the two-week rubidium group (III) and in the cesium-treated group (V) the ratio of intracellular to extracellular potassium concentration was restored to normal. (No ratio is given for Group IV because simultaneous plasma and muscle potassium values were available for only one animal.) The intracellular extracellular tios for rubidium were $118.4 \pm 30.2$ and $116.2 \pm$ 19.7 in the two- and three-week groups, respectively. The ratio for cesium was even higher than this, with a mean value of $185.2 \pm 36.0$. In the 
TABLE III

Concentration ratios

\begin{tabular}{|c|c|c|c|c|}
\hline & $\mathbf{R b}\left(\right.$ or $\left.\mathrm{C}_{\mathbf{s}}\right) \mathbf{u} / \mathbf{K u}^{*}$ & $\mathrm{Rb}$ (or $\mathrm{Cs}$ ) $\mathbf{x} / \mathrm{Rb}$ (or Cs)pt & $\mathbf{K} \mathbf{w} / \mathbf{K}_{\mathbf{p} t}$ & "R"§ \\
\hline I. K-deficient controls & & & $\begin{array}{r}67.7 \\
\pm 16.2\end{array}$ & \\
\hline II. K-added controls & & & $\begin{array}{r}45.7 \\
\pm 4.9\end{array}$ & \\
\hline III. Two-week Rb & $\begin{array}{r}1.23 \\
\pm 0.34\end{array}$ & $\begin{array}{r}118.4 \\
\pm 30.2\end{array}$ & $\begin{array}{r}41.0 \\
\pm 7.9\end{array}$ & $\begin{array}{r}3.11 \\
\pm 1.05\end{array}$ \\
\hline IV. Three-week Rb & $\begin{array}{r}1.61 \\
\pm 0.25\end{array}$ & $\begin{array}{r}116.2 \\
\pm 19.7\end{array}$ & $\|$ & $\begin{aligned} & 2.759 \\
& \pm 0.37\end{aligned}$ \\
\hline V. Two-week Cs & $\begin{array}{r}1.33 \\
\pm 0.21\end{array}$ & $\begin{array}{r}185.2 \\
\pm 36.0\end{array}$ & $\begin{array}{r}42.5 \\
\pm 9.3\end{array}$ & $\begin{array}{r}4.61 \\
\pm 0.81\end{array}$ \\
\hline VI. Normal controls & & & $\begin{array}{r}44.2 \\
\pm 4.1\end{array}$ & \\
\hline
\end{tabular}

* Ratio of rubidium (or cesium) concentration in muscle to that of potassium.

$\dagger$ Ratio of rubidium (or cesium) concentration in muscle to that in plasma.

$\mp$ Ratio of muscle potassium concentration to plasma potassium concentration.

$\$$ Ratio of the two ratios in columns two and three, i.e., $\frac{\mathrm{Rb} \text { (or Cs) } \mathrm{M}}{\mathrm{Rb}(\text { or } \mathrm{Cs})_{\mathrm{P}}} \div \frac{\mathrm{K}_{\mathrm{M}}}{\mathrm{K}_{\mathrm{P}}}$.

$\|$ Omitted because only one simultaneous analysis of $K_{M}$ and $K_{P}$ available.

If Four sets of analyses only.

last column of Table III is given the proportion of the rubidium (or cesium) ratio to the simultaneous potassium ratio (e.g., $\frac{\mathrm{Rb}_{\mathrm{M}}}{\mathrm{Rb}_{\mathbf{P}}} \div \frac{\mathrm{K}_{\mathrm{M}}}{\mathrm{K}_{\mathrm{P}}}$, where the subscripts $\mathrm{M}$ and $\mathrm{P}$ denote concentration in muscle water and plasma, respectively). This value, called " $R$ " in the table, gives an estimate of the relative degrees to which the various alkali ions are concentrated by the muscle. Thus it can be seen that rubidium is concentrated approximately 3 times as much as potassium, while cesium is concentrated 4.6 times as much as potassium.

\section{DISCUSSION}

The foregoing observations confirm and extend the earlier data which had indicated that rubidium and cesium could be taken up in large quantities by muscle cells (6-9). They also confirm the previously reported fact that rubidium chloride lowers the blood $\mathrm{CO}_{2}$ content in alkalotic potassium-deficient rats (9) and extend the observations to demonstrate a similar, but less marked, acidifying effect of cesium chloride. Most significant of all, however, is the evidence presented here that despite very low plasma concentrations of these ions, muscle tissue may accumulate rubidium or cesium up to concentrations 20 to 60 per cent higher than that of potassium. Intracellular potassium concentration may be depressed to extraordinarily low levels and, as shown by the absence of significant change in cellular water content (Table III), this reduction is due to displacement of potassium by the "foreign" alkali ions, rather than simply to intracellular shifts of water accompanying the penetrating ions. Additional evidence against any significant alterations in water distribution was provided by the fact that the water content of whole muscle did not vary significantly in any of the groups.

The concentrations of intracellular potassium given in Table II are considerably lower than the values usually found in potassium depletion alone (10). Actually, the mean values listed in the Tables do not indicate the maximum limits to the replacement of potassium by rubidium or cesium. In individual animals, intracellular rubidium concentrations as high as $120 \mathrm{mEq}$. per L. and potassium concentrations as low as $50 \mathrm{mEq}$. per L. were found. The highest intracellular cesium concentration observed in the cesium experiments was $110 \mathrm{mEq}$. per L., and the lowest potassium concentration $60 \mathrm{mEq}$. per $\mathrm{L}$. Whether even these concentrations represent the limits of the replacement process is not known. Current experiments are designed to study this problem more closely. 
Prior depletion of potassium apparently is not essential for this extensive accumulation of rubidium. In a small group of normal animals fed a mixture of rubidium and potassium in their drinking water for a period of four weeks changes in muscle composition virtually the same as those reported in Table II were found. A few analyses of muscle taken after two or three weeks suggested that in this experiment rubidium had not yet reached its maximum intracellular accumulation at these times. In the experiments on the animals initially depleted of potassium, on the other hand, tissue accumulation of rubidium appeared to be more rapid.

The similarity in composition between the rubidium-treated muscles in the two-week and three-week rubidium groups suggests that a nearequilibrium state had been attained by the end of the second week. Unfortunately, it was not possible to establish this point with certainty by treating animals for longer periods of time because after three weeks on rubidium, or only two weeks on cesium, the rats began to die in increasing numbers. However, even if the present data do not represent a true steady state, the relative chronicity of the experiments, as well as the relative homogeneity of the data, would strongly suggest that equilibrium must have been at least closely approximated. Significant deviations from the steady state caused by possible transient fluctuations in plasma rubidium or cesium concentration following ingestion of these ions would appear unlikely in view of the relatively small variations of the individual plasma values about the group mean. Individual animals were sacrificed at varying time intervals after their last feeding, and if large fluctuations in plasma level had occurred this would have been obvious from the scatter of the data.

The findings of greatest relevance to this study are the concentration ratios listed in Table III. In the rubidium- and cesium-treated groups, the intracellular/extracellular ratios for potassium remained normal at approximately 40 to 1 , but the ratio for rubidium was approximately 3 times this value and the ratio for cesium was about 4.5 times the potassium ratio. It would thus appear that rat skeletal muscle accumulates the alkali metals at equilibrium in a definite order of preference, cesium $>$ rubidium $>$ potassium. Data obtained in a number of recent studies with radioactive tracer doses of rubidium (14-16) or cesium (17) appear to imply somewhat similar conclusions. In these tracer experiments, although no significant amount of intracellular potassium was displaced by the administered ions, the latter accumulated in muscle, red cells and most viscera at tissue plasma concentration ratios equal to, or greater than, those for potassium.

As already pointed out, according to the theory which suggests the passive accumulation of potassium along an electrical gradient established by the "sodium pump," one should expect similar concentration gradients at equilibrium for all three alkali ions, since they would be diffusing passively along the same electrical field. Differences in the mobility of the ions might effect the kinetics of the uptake process, but they would not change the steady-state concentration ratios. Thus, the large differences in gradient actually observed constitute evidence against the theory of passive accumulation. Although it is conceivable that different mechanisms transport each of the ions, the existence of a single process is strongly suggested not only by their close chemical similarity, but also by the fact that each ion appears to inhibit competitively the penetration of the other two into frog muscle (18), as well as into red blood cells $(19,20)$. The simplest conclusion consistent with the available data would seem to be that a single process is responsible for the cellular accumulation of potassium, rubidium and cesium and that this process is not simply a matter of passive diffusion.

If the passive diffusion theory is not valid for muscle, then at least two alternative explanations for the present results seem possible.

The first possibility is that there is an active transport system for which potassium, rubidium and cesium compete. This transport system might be directed inwards, with the order of increasing selectivity being potassium, rubidium, cesium, or the system might be directed outwards and have the reverse order of selectivity. It is also conceivable that the active transport system, whatever its directional orientation, is not selective. If this were the case, the differences in the relative accumulation of these ions could be the result of differences in rates of diffusion in the direction opposite to that of the active transport system. 
The concept of active inward transport in muscle gains indirect support from recent studies with yeast $(3,21)$, green algae $(22)$, and de-sheathed toad nerve fibers (23), which indicate the existence of an active inward transport system for potassium which can operate without the simultaneous efflux of sodium. No direct experimental evidence for the active and independent uptake of potassium by muscle has yet appeared, but this concept is at least consistent with the fact that movements of sodium and potassium in and out of muscle do not always occur simultaneously and in a fixed stoichiometrical relationship $(3,24,25)$ as might be expected if potassium accumulation were entirely and directly dependent upon a "sodium pump." It has recently been pointed out that the concentration ratio for potassium in frog muscle somewhat exceeds that predictable simply from the transmembrane potential difference, further suggesting the possibility of some active chemical force responsible for potassium accumulation (26).

A second alternative to the "passive diffusion" theory is suggested by the analogy between the relative concentration gradients for the alkali metals observed in these experiments and the behavior of certain ion exchange resins, which selectively bind these ions in the same order of preference. Selective binding of cations by fixed negative charges inside the cell has already been proposed as a mechanism for the normal accumulation of intracellular potassium (27). This hypothesis gains some support from the recent observation that relatively high concentrations of potassium are apparently maintained in frog muscle which has been soaked in potassium-free Ringer solution and poisoned with cyanide plus iodoacetate (25). On the other hand, selective binding of cations within the cell would be expected to result in significant reductions in tissue osmotic activity as intracellular potassium is displaced by cations like rubidium or cesium, for which the fixed negative charges have a higher affinity. The absence of any evidence of water shifts in these experiments therefore indicates either that large-scale binding does not occur, or that there exist cellular mechanisms which maintain total osmotic constancy despite fluctuations in cation activity.

At present there is no experimental basis for a choice among these or any other alternatives to the passive diffusion theory of potassium uptake. Obviously, much more information is required before an adequate description of potassium transport in muscle cells can be given.

\section{SUMMARY AND CONCLUSIONS}

Chronic feeding of equivalent amounts of rubidium and potassium or cesium and potassium to young rats resulted in replacement of half or more of the muscle potassium by rubidium or cesium. The final tissue-plasma concentration ratios for rubidium were approximately 3 times that for potassium, and the ratio for cesium was more than 4.5 times the potassium ratio.

The results suggest that muscle cells accumulate the alkali metals in a definite order of preference : cesium $>$ rubidium $>$ potassium. This fact is construed as evidence against the normal accumulation of potassium solely by passive diffusion along an electrical gradient produced by a "sodium pump," and two alternative explanations are discussed which would appear to be more consistent with the present observations.

\section{REFERENCES}

1. Dean, R. B., Theories of electrolyte equilibrium in muscle. Biol. Symposia, 1941, 3, 331.

2. Krogh, A., Croonian Lecture: The active and passive exchanges of inorganic ions through the surfaces of living cells and through living membranes generally. Proc. Roy. Soc., London, s. B., 1946, $133,140$.

3. Conway, E. J., Some aspects of ion transport through membranes. Symposia Soc. Exper. Biol., 1954, 8, 297.

4. Steinbach, H. B., The regulation of sodium and potassium in muscle fibers. Symposia Soc. Exper. Biol., 1954, 8, 438.

5. Relman, A. S., The physiological behavior of rubidium and cesium in relation to that of potassium. Yale J. Biol. \& Med., 1956, 29, 248.

6. Mendel, L. B., and Closson, O. E., The paths of excretion for inorganic compounds. III. The excretion of rubidium. Am. J. Physiol., 1906, 16, 152.

7. Mitchell, P. H., Wilson, J. W., and Stanton, R. E., The selective absorption of potassium by animal cells. II. The cause of potassium selection as indicated by the absorption of rubidium and cesium. J. Gen. Physiol., 1921, 4, 141.

8. Heppel, L. A., and Schmidt, C. L. A., Studies on the potassium metabolism of the rat during pregnancy, 
lactation and growth. Univ. California Publ., Physiol., 1938, 8, 189.

9. Relman, A. S., Roy, A. M., and Schwartz, W. B., The acidifying effect of rubidium in normal and potassium-deficient alkalotic rats. J. Clin. Invest., 1955, 34, 538.

10. Cotlove, E., Holliday, M. A., Schwartz, R., and Wallace, W. M., Effects of electrolyte depletion and acid-base disturbance on muscle cations. Am. J. Physiol., 1951, 167, 665.

11. Steel, A. E., Separation and identification of alkali metals on paper chromatograms. Nature, London, $1954,173,315$.

12. Kolthoff, I. M., and Sandell, E. B., Textbook of Quantitative Inorganic Analysis, 3rd ed. New York, The Macmillan Co., 1952, pp. 395-398.

13. Levinsky, N., Allen, J. M., Connors, H. P., and Relman, A. S., Unpublished data.

14. Love, W. D., Romney, R. B., and Burch, G. E., A comparison of the distribution of potassium and exchangeable rubidium in the organs of the dog, using rubidium ${ }^{86}$. Circ. Research, 1954, 2, 112.

15. Tyor, M. P., and Eldridge, J. S., A comparison of the metabolism of rubidium ${ }^{86}$ and potassium ${ }^{2}$ following simultaneous injection into man. Am. J. M. Sc., 1956, 232, 186.

16. Kilpatrick, R., Renschler, H. E., Munro, D. S., and Wilson, G. M., A comparison of the distribution of ${ }^{82} \mathrm{~K}$ and ${ }^{88} \mathrm{Rb}$ in rabbit and man. J. Physiol., 1956, 133, 194.

17. Hood, S. L., and Comar, C. L., Metabolism of cesium-137 in rats and farm animals. Arch. Biochem. \& Biophys., 1953, 45, 423.

18. Ling, G. N., Selective cellular permeability according to the fixed charge hypothesis. Proc. Internat. Physiol. Congress, 1953, p. 566.
19. Solomon, A. K., The permeability of the human erythrocyte to sodium and potassium. J. Gen. Physiol., 1952, 36, 57.

20. Burch, G. E., Threefoot, S. A., and Ray, C. T., The rate of disappearance of $\mathrm{Rb}^{86}$ from the plasma, the biologic decay rates of $\mathrm{Rb}^{\mathrm{s}}$, and the applicability of $\mathrm{Rb}^{86}$ as a tracer of potassium in man with and without chronic congestive heart failure. J. Lab. \& Clin. Med., 1955, 45, 371.

21. Rothstein, A., and Enns, L. H., The relationship of potassium to carbohydrate metabolism in baker's yeast. J. Cell. \& Comp. Physiol., 1946, 28, 231.

22. Scott, G. T., and Hayward, H. R.,, Evidence for the presence of separate mechanisms regulating potassium and sodium distribution in ulva lactuca. J. Gen. Physiol., 1954, 37, 601.

23. Shanes, A. M., and Berman, M. D., Penetration of the desheathed toad sciatic nerve by ions and molecules. I. Steady state and equilibrium distributions. J. Cell. \& Comp. Physiol., 1955, 45, 177.

24. Cooke, R. E., Segar, W. E., Cheek, D. B., Coville, F. E., and Darrow, D. C., The extrarenal correction of alkalosis associated with potassium deficiency. J: Clin. Invest., 1952, 31, 798.

25. Shaw, F. H., and Simon, S. E., The nature of the sodium and potassium balance in nerve and muscle cells. Australian J. Exper. Biol. \& M. Sc., 1955, 33, 153.

26. Harris, E. J., Transport and Accumulation in Biological Systems. New York, Academic Press, Inc., 1956, pp. 166-169.

27. Ling, G. N., The role of phosphate in the maintenance of the resting potential and selective ionic accumulation in frog muscle cells in Phosphorus Metabolism, Vol. 2, W. D. McElroy and Bentley Glass, Eds. Baltimore, The Johns Hopkins Press, 1952, p. 748. 